\title{
The Effect of Soursop Juice Consuming on Uric Acid Level in the Elderly
}

\author{
$1^{\text {st }}$ Anita Apriany \\ Nursing Study Program \\ STIKes Muhammadiyah Palembang \\ Palembang, Indonesia \\ apriany47@gmail.com \\ $4^{\text {th }}$ Hikmah Ramadhan \\ Nursing Study Program \\ STIKes Muhammadiyah Palembang \\ Palembang, Indonesia
}

\author{
$2^{\text {nd }}$ Maya Fadlillah \\ Nursing Study Program \\ STIKes Muhammadiyah Palembang \\ Palembang, Indonesia
}

\author{
$3^{\text {rd }}$ Puji Setya Rini \\ Nursing Study Program \\ STIKes Muhammadiyah Palembang \\ Palembang, Indonesia
}

\begin{abstract}
Background: Uric acid is a crystalline acid that is the end product of purine metabolism (a nucleoprotein derived form). Purines are the result of protein metabolism that can form uric acid crystals and can accumulate in the joints of the hands and kidneys / urinary tract. How to care for uric acid is to consume soursop juice a lot of vitamin $C$. Research Objectives: To determine the effect of soursop juice consumption on uric acid levels in the elderly age. Research Methods: This study is a quasiexperiment with a pre-post design group design design with a quantitative approach. Sampling technique is total sampling that is all elderly who suffering from uric acid which amounts to 15 population. Results. The mean uric acid levels before the action were 8,540 minimum levels of 6.2 and maximum 13.0 with standard deviation of 1.8631, Confidence interval 7,508-9,572 and average uric acid levels after action were 6,380 minimum levels of 5.0 and maximum of 8.7 with standard deviation of 1,359 , Confirmation Interval 5,751-7,009. Conclusion: Based on statistical test with Tair Paired Samples Test showed the influence of Soursop Juice Consume Against Uric Acid Level in Elderly (p value 0.000 ).
\end{abstract}

Keywords-Soursop Juice, Uric Acid, Elderly

\section{INTRODUCTION}

Old age is seen as a period of biological degeneration accompanied by various sufferings due to various diseases that accompany the aging process. But it is an advanced stage of a life process that is marked by a decrease in the ability for the body to adapt to environmental stress. Decreased ability to function organs, and body systems that are natural or physiological. The decrease is due to the reduced number and ability of body cells. In general, signs of the aging process began to appear since the age of 45 years and will cause problems at around 60 years of age [5].

According to data from the East Java Health Office in 2010 the number of elderly population was 7,956,188 people with 10 diseases most elderly visitors at the community health centre in East Java Province namely; hypertension, myalgia, ARI, gastritis, skin disease, diabetes mellitus, lung disease, asthma, and gout.
Diseases predominate in elderly diseases including hypertension, diabetes mellitus and gout [5].

World Health Organization (WHO) reports that the incidence of rheumatism in 2008 reached $20 \%$ of the world's population affected by the disease, where $5-10 \%$ are those aged 5-20 years and 20\% are those aged 55 years (Wijoyo, 2010 in Nadliroh, 2014). Based on the latest research results from Zeng et al 2008, the prevalence of gout pain in Indonesia reaches 23.6 to $31.3 \%$, this figure shows that pain due to gout has greatly disrupted the activities of the Indonesian people [3.]

Uric acid is an acid in the form of crystals that is the end result of purine metabolism (a form of nucleoprotein derivatives), which is a component of nucleic acids found in the nucleus of body cells. Purines are the result of protein metabolism that can form uric acid crystals and can accumulate in the joints of the hands and kidneys / urinary tract (MOH RI, 2011). Naturally, purines are found in our bodies and are found in all food from living cells, which is food from plants (vegetables, fruits, nuts) or animals (meat, innards, sardines). An increase in uric acid levels in the blood above the normal value is called hyperuricemia [5].

Gout is influenced by foods high in purines, alcohol, age, gender, genetics, obesity, heavy body activity, smokers, wrong lifestyle and deficiency of the enzyme hypoxantine guanine phosphoribosyl transferase (HGPRT) [3]. Some groups of drugs for the treatment of gout are Uricosuric drugs, Xanthine Oxidase inhibitors, nonsteroidal anti-inflammatory which can cause frequent side effects such as kidney disorders and gastrointestinal disorders . Vitamin $\mathrm{C}$ or ascorbic acid is a water-soluble vitamin that is easily lost during the cooking process, vitamin $\mathrm{C}$ food cannot be stored in the body so it takes the consumption of foods containing vitamin $\mathrm{C}$ every day, vitamin $C$ is needed by the body to build and maintain body cells and maintain healthy teeth and gum. Vitamin C deficiency can cause injuries to fail to heal, weakened bones, muscle degeneration, and increase the risk of infection and falls in the elderly. Vitamin $\mathrm{C}$ is found in citrus fruits, strawberries, soursop, tomatoes and vegetables [2]. 
According to Lalage, (2013) in Maryati, (2014) The most dominant vitamin in soursop fruit is vitamin C, which is about $20 \mathrm{mg} / 100 \mathrm{gr}$ of fruit flesh. The content of vitamin $\mathrm{C}$ in soursop juice serves as an antioxidant and has the ability to inhibit the production of the enzyme xanthine oxidase. Therefore, soursop juice can inhibit the formation of uric acid in the body (Lalage, 2013) and vitamin $\mathrm{C}$ can also help increase the excretion (removal) of uric acid through urine. With this ability, uric acid levels in the body can be reduced) [11].

Antioxidant properties found in soursop can reduce the formation of uric acid by inhibiting the production of the enzyme xanthine oxidase, antioxidants have the ability to inhibit the production of the enzyme xanthine oxidase, which can inhibit the process of uric acid formation in the body. Antioxidants can help blood circulation and shed uric acid in the blood. That way, levels of purines in the blood can be reduced so that sufferers can work as usual [7].

Several studies on the effect of consuming soursop juice on uric acid levels, namely Yantina, Y. (2016) shows that soursop juice can reduce uric acid levels by 0.5-2.5 dl.mg. Further research by Maryati, H (2013) that consuming soursop juice can reduce uric acid levels by $93 \%$ from 16 people in the treatment group and $28.6 \%$ from 16 people in the control group.

Based on the background, the researcher needs to conduct research on "The Effect of Soursop Juice on Uric Acid Levels in the Elderly in Palembang's Tresna Werda Lotus Orphanage in 2017".

TABLE 1. URIC ACID LEVELS BEFORE ACTION AT THE ELDERLY SOCIETY
\begin{tabular}{|c|c|c|c|c|c|}
\hline Variable & Mean & Min & Max & SD & CI 95\% \\
\hline $\begin{array}{c}\text { Uric Acid Levels Before } \\
\text { Action }\end{array}$ & 8.540 & 6.2 & 13.0 & 1.8631 & $7.508-9.572$ \\
\hline
\end{tabular}

Based on the table 1, it was found that from 15 respondents, the average uric acid level before the action was 8.540 minimum levels 6.2 and maximum 13.0 with a

\section{METHOD}

This type of research is quantitative with the research design Quasi Experiment with the design used is the design of One Group Pretest-Postest Disigh without the control group but the first observation (pretest) has been made that allows researchers to test changes that occur after the experiment (posttest) [7].

Quasi experimental design is a design that does not have strict restrictions on randomization and at the same time can control the threats of validity [8].

The One Group Pretest-Postest design uses one group of subjects. First measured, then subject to treatment for a certain period of time, then the measurement is made a second time. The form of this research design is as follows [9].

\section{DISCUSSION}

Based on the results of the analysis presented in the form of frequency distribution tables and percentages of the results of the study before the intervention and after the intervention at the Tresna Werdha Lotus Palembang Social Home in 2017, the following figure is obtained.

\section{A. Univariate Analysis}

Distribution of uric acid levels in the elderly before given Soursop juice

TABLE 2. URIC ACID LEVELS AFTER ACTION AT SOCIAL HOME

\begin{tabular}{|c|c|c|c|c|c|}
\hline Variable & Mean & Min & Max & SD & CI 95\% \\
\hline $\begin{array}{c}\text { Uric Acid Levels Before } \\
\text { Action }\end{array}$ & 6.380 & 5.0 & 8.7 & 1.359 & $5.751-7.009$ \\
\hline
\end{tabular}

Based on the above table, it was found that from 15 respondents, the average level of uric acid after the action was 6,380 minimum levels of 5.0 and a maximum of 8.7 with a standard deviation of 1,359, Confidence Intervals TABLE 3. DIFFERENCES IN URIC ACID LEVELS BEFORE AND AFTER THE ACTION AT TRESNA WERDA TERATAI PALEMBANG SOCIAL HOME

\begin{tabular}{cccc}
\hline Variable & Mean & Standard Deviation & \multirow{2}{*}{ Sig $(\boldsymbol{p})$} \\
\hline uric acid levels before action & 8.540 & 1.8631 & \multirow{2}{*}{0.000} \\
\hline uric acid levels after action & 6.380 & 1.1359 & \\
\hline
\end{tabular}

Based on statistical tests with the T Paired Sample Test, the test shows that the average uric acid level before the action is 8,540 with a standard deviation of 1.8631 while the uric acid level after the action is 6,380 with a standard deviation of 1,1359 and obtained with a $\mathrm{p}$ value standard deviation of 1.8631, Confidence Interval 7.5089.572 .
5,751-7,009. This test is carried out to determine the conclusions ho accepted which means that there is an influence of uric acid levels before and after the action. of 0,000 . This means that there is a difference between uric acid levels before and after the action.

The Effect of Soursop Juice on Uric Acid Levels in the Elderly in Palembang's Tresna Werda Lotus Orphanage in 2017, based on statistical tests with the T Paired Sample Test, the test shows that the average uric 
acid level before the action is 8,540 with a standard deviation of 1.8631 while the uric acid level after the action is 6,380 with a standard deviation of 1,1359 and obtained with a $p$ value of 0,000 . It means that there is a difference between uric acid levels before and after the action.

According to the content of vitamin $\mathrm{C}$ in soursop juice functions as an antioxidant and has the ability to inhibit the production of the xanthine oxidase enzyme. Therefore, soursop juice can inhibit the formation of uric acid in the body. Vitamin $C$ can help increase urinary acid excretion. With this ability, uric acid levels in the body can be reduced. Vitamin $\mathrm{C}$ or ascorbic acid is a watersoluble vitamin that is easily lost during the cooking process, vitamin $\mathrm{C}$ food cannot be stored in the body so it takes the consumption of foods containing vitamin $\mathrm{C}$ every day, vitamin $\mathrm{C}$ is needed by the body to build and maintain body cells and maintain healthy teeth and gum. Vitamin $\mathrm{C}$ deficiency can cause injuries to fail to heal, weakened bones, muscle degeneration, and increase the risk of infection and falls in the elderly. Vitamin $\mathrm{C}$ is found in citrus fruits, strawberries, soursop, tomatoes and vegetables [2].

The results of this study are in line with research conducted in research and the effect of soursop juice consumption on decreasing levels of uric acid in blood in gout arthritis patients aged 46-50 years in the working area of Peterongan Jombang Public Health Center is known that the average levels of uric acid respondents before (Pre) given soursop juice 8,087 and after (Post) given soursop juice average uric acid levels of 6.707 with a standard deviation of 2.2386 and 2.4835 with $\mathrm{p}$ value $=$ 0.001 , there are significant differences between before and after administration soursop juice [10].

The results of this study are also in line with the results of the study by Wardani, RE (2015) the effect of soursop juice therapy on decreasing uric acid levels in elderly women in Gayaman Village Mojoanyar District Mojokerto District showed the results showed that the average level of uric acid before administering soursop juice therapy was $7.41 \mathrm{mg} / \mathrm{dl}$ and after giving soursop juice therapy for 2 weeks as much as 1 time a day the average uric acid level of respondents to $6.18 \mathrm{mg} / \mathrm{dl}$. Here it can be seen a decrease in respondent uric acid levels which is equal to $1.37 \mathrm{mg} / \mathrm{dl}$. Statistical test results obtained $p=0.001$ with $\alpha \leq 0.05$ so it can be said that there is an effect of soursop juice therapy on decreasing uric acid levels in elderly women [10].

Based on the results of this study, researchers argue that a decrease in uric acid levels in the elderly who suffer from gout after consuming soursop juice every morning once a day for 14 days. This is caused by the soursop fruit content which is rich in antioxidants and vitamin $\mathrm{C}$. Because of the high antioxidants and vitamin $\mathrm{C}$ in soursop juice so that the levels of uric acid in the blood become low. Vitamin $\mathrm{C}$ is a micronutrient that plays a role in a variety of enzymatic and non-enzymatic reactions. Increased concentration of Vitamin $\mathrm{C}$ can inhibit uric acid reabsorption (the filtering process of metabolic waste which is the process of re-absorption of glomerular filtrate that can still be used by the body). Vitamin $\mathrm{C}$ modulates the serum concentration of uric acid through its uricosuric effect. Vitamin $\mathrm{C}$ and uric acid are absorbed through anion exchange in the renal proximal tubule and then excreted in the urine.

\section{CONCLUSION}

Based on the results of respondents' research on the effect of consuming soursop juice on uric acid levels in the elderly at Tresna Werda Lotus Social Home in Palembang with a sample of 15 respondents concluded as follows:

1. The average level of uric acid before the action is 8,540 minimum level 6.2 and maximum 13.0 with standard deviation 1.8631, Confidence Interval 7.508-9.572.

2. The average level of uric acid after the action is 6,380 minimum levels of 5.0 and a maximum of 8.7 with a standard deviation of 1,359, Confidence Intervals 5,751-7,009.

3. There is an effect of consuming soursop juice on the levels of gout in the elderly at Palembang's Tresna Werda Lotus Orphanage in 2017 (p value 0.000).

\section{ACKNOWLEDGMENTS}

Thanks to the chairman of the Muhammadiyah Palembang STIKes, the Head of the P2M institution, that has support for this research.

\section{REFERENCES}

[1] Arikunto, Suharsini. 2010. Metodelogi Penelitian. Jakarta: Rineka cipta

[2] Dewi, S.R. 2014. Buku Ajar: Keperawatan Gerontik. Ed.1 Cet.1 Yogyakarta. Deppublish

[3] Fatimah. 2010. Gizi Usia Lanjut. Jakarta: Erlangga.

[4] Lingga Lanny, 2012. Bebas Penyakit Asam Urat Tanpa Obat Jakarta. Agromedia Pustaka

[5] Maryam, dkk. 2012. Mengenal Usia Lanjut Dan Perawatannya. Jakarta: Salemba Medika.

[6] Nadliroh Uyun. 2014. Gambaran Penyakit Rematik pada Lansia di Panti Wreda Dharma Bakti Surakarta.

[7] Noormindhawati, L. 2013. Jus Sakti Tumpas Penyakit Asam urat Jakarta: Pustaka Makmur

[8] Notoatmodjo, Soekidjo. 2010. Metode Penelitian Kesehatan Jakarta: Rineka Cipta.

[9] Nursalam. 2011. Konsep dan Penerapan Metodologi Penelitian Ilmu Keperawatan. Jakarta: Salemba Medika.

[10] Prihatmo, Parjana E. 2011.Khasiat Sehat Sirsak. Yogyakarta: Selingkar Rumah Idea Pustaka

[11] Sutanto, T. 2013. Basmi Penyakit dengan Jus Ampuh. Khasiat Ampuh Jus, Basmi Penyakit Tanpa Efek Samping. Cet.1. Yogyakarta. Buku Pinta. 